\title{
THE FISHES OF OKINAWA, ONE OF THE RIU KIU ISLANDS.
}

\author{
By John Otterbein SNyder, \\ of Stanford University, California.
}

This account of the fishes of Okinawa is based on a collection made by members of the United States Bureau of Fisheries steamer Albatross at the time of her cruise during 1906 in the north Pacific Ocean and along the shores of Japan. On the arrival of the Albatross in Japan, the writer and Mr. Michitaro Sindo, a student of Stanford University, were detached from the vessel and intrusted with a study of the shore fishes. The party visited various points along the coast from Otaru in Hokkaido to Okinawa, one of the Riu Kiu Islands. Five days beginning with August 13 were spent at the latter place, most of the time being consumed in an examination of the tide pools near Naha and Itoman. The market, open for an hour or two each evening, was regularly visited and an attempt made to procure specimens of each species that appeared there.

The excellent results obtained from our short stay at Naha were made possible through the kindly interest of Baron Shigeru Narahara, governor of the Province, the chief and other officers of the police force of Naha, the town officials of Itoman, and the teachers of the fisheries school at the same place.

Okinawa, the largest of the Riu Kiu or Luchu Islands, lies about halfway between Kiu Siu and Formosa, directly in the path of the Kuro Shiwo, the great warm current that passes northward along the eastern shores of Japan. Its climate is hot and humid. The island appears to be a coral formation, no volcanic or sedimentary rocks appearing on the surface. Near the harbor of Naha the coast is fringed with growing coral reefs, and the rocks near shore are conglomerates of disintegrated corals. The outlying reefs, the gently sloping beaches, seamed and carved by the tides, and the intervening region of broken corals and beds of sand and mud offer retreats for vast numbers of fishes and other marine forms. ${ }^{1}$

\footnotetext{
1 Interesting in this connection is the rather naive account of Bayard Taylor in the narrative of the expedition to Japan under the command of Commodore Perry. In his description of the port of Naha Taylor says: "Here the little pools which seamed the surface were alive with crabs, snails, starfish, sea-
} 
A list of the fishes known from the Riu Kiu Islands, published by Jordan and Starks, ${ }^{1}$ records 54 species as occurring at Okinawa. However, this small number, together with a few others from the islands near by, furnished material for the observation that the fish fauna is fully tropical, composed of forms having a wide distribution among the coral islands of Polynesia with some species characteristic of the coasts of southern Japan and China. This conclusion easily stands in the presence of a more thorough study made possible by the collection in the hands of the present writer.

Nearly 60 per cent of the species listed in the present report are characteristic of the East Indies, the Philippines, and Polynesia, about a third of these being known only from Polynesia. Not more than 20 per cent occur in Japan, and most of these are indigenous to the southern coasts, not extending their range north of Misaki. Some of these Japanese species are also found far to the south through the Philippines and Polynesia and also in the East Indies. The remainder includes a few forms which are cosmopolitan, and a considerable number which have thus far been seen only near Okinawa.

It is not presumed that the following list of Okinawa fishes, although recording 293 species, ${ }^{2}$ includes more than a part of the great number occurring there. That the fauna is rich in species is amply shown by the large number obtained in so short a time from the pools and the small market, the great fringe of reefs remaining untouched. The many forms recorded without further note are represented by one or more specimens secured in the market, nothing having been learned during the short stay of the party concerning their relative abundance, habits, distribution, or value as food.

The color notes on fishes from the pools were made from living examples. Those based on market specimens were taken from

prickles, and numerous small fish of the intensest blue color. We found several handsome shells clinging to the coral, but all our efforts to secure one of the fish failed. The tide was ebbing so fast that we were obliged to return for fear of grounding the boat. We hung for some time over the coral banks, enraptured with the beautiful forms and colors exhibited by this wonderful vegetation of the sea. The coral grew in rounded banks, with clear, deep spaces of water between, resembling in miniature ranges of hills covered with autumnal forests. The loveliest tints of blue, violet, pale green, yellow, and white gleamed through the waves, and all the varied forms of vegetable life were grouped together, along the edges of cliffs and precipices, hanging over the chasms worn by currents below. Through these paths, and between the stems of the coral groves, the blue fish shot hither and thither like arrows of the purest lapis lazuli; and others of a dazzling emerald color with tails and fins tipped with gold, eluded our chase like the green bird in the Arabian story. Far down below, in the dusky depth of the waters, we saw, now and then, some large brown fish, hovering stealthily about the entrances to the coral groves, as if lying in wait for their bright little inhabitants. The water was so clear that the eye was deceived as to its depth, and we seemed now to be resting on the branching tops of some climbing forest, now to hang suspended in midair between the crests of two opposing ones. Of all the wonders of the sea which have furnished food for poetry and fable this was assuredly the most beautiful."

1 Proc. U. S. Nat. Mus., vol. 32, 1907, p. 491-501.

2 Species previously recorded from Okinawa and not represented in the Albatross collection are included in footnotes. 
individuals just dead, they having been transferred at once from the live wells of the boats to the place of sale.

Descriptions of the new species have been published in previous volumes of these Proceedings.

The drawings were made by Mr. W. S. Atkinson.

The writer acknowledges with pleasure his obligations to Dr. David Starr Jordan for assistance in matters pertaining to nomenclature, and to Dr. C. H. Gilbert, who, as naturalist in charge of the Albatross expedition, made this study possible.

\section{Family SCYLIORHINID王.}

STEGOSTOMA TIGRINUM (Gmelin).

One small specimen, with the yolk sack attached, was seen in the collection of the fisheries school at Itoman near Naha.

Family ÆTOBATIDÆ.

AETOBATIS TOBIJEI (Bleeker).

\section{Family ELOPIDÆ.}

ELOPS HAWAIENSIS Regan.

One specimen agrees almost perfectly with examples from Hawaii. Vertebræ, 68; scales, 94; interorbital space, 5.5 in head; pectoral, 2; gillrakers, 14; lower jaw included. This represents the E. machnata of Temminck and Schlegel, and it is probable that no other form occurs in Japan or the Riu Kiu Islands. Many were seen in the markets.

MEGALOPS CYPRINOIDES (Broussonet).

\section{Family CLUPEID E.}

CLUPEA OKINAWENSIS Kishinouye.

Small specimens were seined in shallow water near shore.

$$
\text { Family SYNODONTIDÆ. }{ }^{1}
$$

SYNODUS JAPONICUS (Houttuyn).

SAURIDA ARGYROPHANES (Richardson).

SAURIDA GRACILIS (Quoy and Gaimard).

$$
\text { Family PLOTOSID E. }
$$

PLOTOSUS ANGUILLARIS (Bloch).

Seined in shallow water near the shore. 


\section{Family LEPTOCEPHALIDÆ.}

LEPTOCEPHALUS MARGINATUS (Valenciennes).

Many were seen in the market. One small example has the pectoral blotch scarcely visible.

\section{Family MYRIDÆ.}

MURAENICHTHYS OWSTONI Jordan and Snyder.

In several small examples from the pools the snout is slightly more pointed than in the type-specimen. The slit of the posterior nostril divides the lip just anterior to the eye.

\section{Family OPHICHTHYIDÆ. ${ }^{1}$}

MICRODONOPHIS POLYOPHTHALMUS (Bleeker).

An eel from the market is identified as a specimen of this species, although it does not agree in color with the example figured by Bleeker. $^{2}$ Color in life, brownish gray, white beneath, the snout and tail yellow; body with ocelli which are gray within tinged with lavender, the borders dark brown, surrounded with reddish orange which fades off into the body color; ventrally the ocelli become brown spots surrounded with orange; ocelli of head lemon yellow within, the margins brown, growing lighter on sides of head, yellow beneath; nostril tubes orange.

\section{PISOODONOPHIS CANCRIVORUS (Richardson).}

An example measuring 600 millimeters, from the Naha market, does not differ from a larger specimen from Manila.

\section{MYRICHTHYS RUPESTRIS, new species.}

A small eel representing a species of Myrichthys that appears to be undescribed was obtained at Okinawa by Capt. Alan Owston.

Head 15.5 in length; 5.5 in trunk; head and trunk 1.3 in tail; depth in region of vent 3 in head; eye 8.5 in head; snout 5 ; cleft of mouth 3.5 ; length pectoral 7.5 ; pectoral rays 14 .

The body is very elongate and snakelike, the depth being greatest in the pectoral region, decreasing immediately behind it and remaining about the same ( 3 in head), to the posterior third of caudal where the tail gradually tapers to a rather sharp point. The body is not quite cylindrical, the depth being somewhat greater than the width. Snout elongate, not very blunt, overhanging the lower jaw so that the teeth may be seen from below. Cleft of mouth extending considerably beyond eye. Labial nostrils large, overhanging and 
concealing tip of lower jaw when viewed from the side. Gill-cleft wider than eye, narrower than length of snout, below middle of head, and oblique in position. Teeth blunt; in 2 series on jaws, vomer and palatines. Dorsal fin originating on occiput halfway between tip of snout and gill-opening, increasing in height to near middle of body where it measures 1 in the snout, 5 in the head. Caudal originating immediately behind anal opening and extending to near tip of tail where it disappears at a point below end of dorsal, the portion of tail without fins being equal in length to the snout. Base of pectoral equal in length to gill-opening; rays of fin branched, the middle ones longest.

Color in spirits: Body tinted with brown above, lighter below; body and tail with 3 series of rounded or elongate dark brown spots; the upper series lying along the dorsal fin, many of the spots being cut by the base of it, those of each side alternating in position; median series 25 in number, extending along side of body and tail, alternating in position with those of upper and lower series; ventral series small and somewhat irregular on the trunk, larger and more regular on the tail, where they are arranged along the base of anal alternating in position with those of the opposite side; tip of tail light; dorsal fin with dark spots each of which corresponds in position with one on the body at base of fin, there being about twice as many spots on the fin as on either side of body at its base; pectorals and anal immaculate; head with a large oval spot above gill-opening, a much smaller one above and behind eye, and another halfway between these; small spots below eye and on chin and throat; tip of snout immaculate.

This species closely resembles $M$. tigrinis of the Central American coast. It is colored much like this form, and the body has the same nearly cylindrical shape, but it is a great deal more slender, specimens of $M$. tigrinis of equal length being almost twice as deep and having very much larger heads. The snout is more obtuse in $M$. rupestris.

M. magnificus of Hawaii has a shorter and deeper body which is compressed rather than cylindrical, a longer snout, and from 20 to 22 spots in the lateral row. Three specimens of this species were lately collected by the writer in the tide pools near Honolulu, the first to be seen since the species was discovered in 1835 . These specimens, which were carefully preserved, agree with the original description except in the following particulars. The body is decidedly compressed, rather than cylindrical; the very small pectoral fin has 11 instead of 20 rays, the tips having no doubt been counted thus enumerating the branches; the teeth are not acute, but on the contrary have rounded points. The color which has changed very little from that of life is almost exactly as originally described, the dorsal however being spotted much like that of $M$. rupestris. 
The following table records some measurements of the Okinawan and the Hawaiian specimens:

\begin{tabular}{|c|c|c|c|c|}
\hline & $\begin{array}{r}\begin{array}{c}\text { Myrich- } \\
\text { thys } \\
\text { rupestris. }\end{array} \\
415\end{array}$ & \multicolumn{3}{|c|}{ Myrichthys magnificus. } \\
\hline 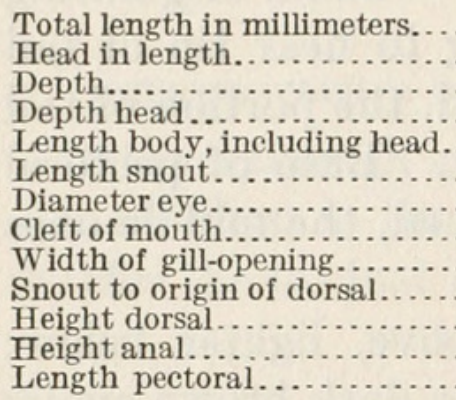 & $\begin{array}{l}415 \\
.062 \\
.02 \\
.028 \\
.042 \\
.011 \\
.006 \\
.016 \\
.01 \\
.04 \\
.011 \\
.009 \\
.01\end{array}$ & $\begin{array}{l}400 \\
.067 \\
.035 \\
.03 \\
.042 \\
.015 \\
.005 \\
.018 \\
.01 \\
.034 \\
.015 \\
.007 \\
.008\end{array}$ & $\begin{array}{l}312 \\
.072 \\
.03 \\
.032 \\
.043 \\
.016 \\
.007 \\
.017 \\
.007 \\
.05 \\
.016 \\
.01\end{array}$ & $\begin{array}{l}356 \\
.07 \\
.032 \\
.031 \\
.043 \\
.015 \\
.007 \\
.016 \\
.04 \\
.015 \\
.01\end{array}$ \\
\hline
\end{tabular}

Type-specimen-Cat. No. 74048, U. S. Nat. Mus.

\section{Family MURÆNIDÆ. ${ }^{1}$}

GYMNOTHORAX MELEAGRIS (Shaw).

GYMNOTHORAX LAYSANUS (Steindachner).

A specimen 390 millimeters long from a tide pool near Naha is almost exactly like an example from Hawaii. The head and body are closely covered with white spots which grow larger and fewer posteriorly. These white spots are on a brownish background which has numerous black spots about as large as the eye.

GYMNOTHORAX PICTUS (Ahl).

Finely clouded with brown and yellowish gray in life, the color soon fading after death to pale brownish gray and white.

\section{GYMNOTHORAX UNDULATUS (Lacépède). \\ GYMNOTHORAX PETELLI (Bleeker). \\ GYMNOTHORAX STELLATUS (Lacépède).}

Three specimens, one of which is like several collected at Samoa by Doctor Jordan. The spots are about the size of the eye and are scattered over the body, only the upper ones tending to arrange themselves in a row. Another has the spots larger and not arranged in rows. It is possible that both the Okinawa and Samoa specimens are representatives of $M$. fimbriatus Bennett, figured and described by Bleeker as $G$. isingleenoides. ${ }^{2}$

\section{GYMNOTHORAX ALBIMARGINATUS (Temminck and Schlegel).}

In life, brownish gray, darker posteriorly, the fins growing more dark toward the edges where they are narrowly bordered with dead white; anterior portion of body finely reticulated with pale yellowishgray lines; snout and region about jaws tinged with salmon red; iris reddish orange. 
Head 3.5 in trunk; 4 in tail; snout 6 in head; eye 1.7 in snout. Teeth uniserial, growing gradually smaller from before backwards; no enlarged canines; some teeth depressible, others apparently embedded in the jaw. Diameter of gill-opening about equal to that of eye.

The above description is of a specimen 900 millimeters long. Another, 320 millimeters long, had life colors similar to the above, but differed as follows; head 2.5 in trunk; 4 in tail; snout 5.5 in head; eye 2 in snout; teeth biserial.

GYMNOTHORAX PHILIPPINUS Jordan and Seale.

One specimen, the second of this species that has been recorded, was obtained in the Naha market. It resembles the type very closely.

Suspecting that this species might be synonymous with Muraena reevesi Richardson, ${ }^{1}$ which Günther records from Japan, the writer asked Mr. Henry W. Fowler to compare Richardson's description and figure with that of Jordan and Seale. Mr. Fowler writes: "Although apparently very closely related, I should be inclined to consider the two species provisionally distinct. $M$. reevesi has the spots on the dorsal and anal large and rather sparce, similar to those on the trunk, and arranged in two irregular series, one marginal and the other basal. There are no median, smaller ones as in G. philippinus. M. reevesi has the gill-opening distinctly black. There are also 5 large, dusky blotches between eye and gill-opening, and a small, dark one just over gill-opening. $\quad M$. reevesi further displays a large dark blotch on ramus of mandible near its articulation, and the thorax and abdomen are rather obscurely mottled."

GYMNOTHORAX CHLAMYDATUS Snyder.

Plate 62, fig. 1.

Gymnothorax chlamydatus SNYDER, Proc. U. S. Nat. Mus., vol. 35, 1909, p. 94.

Two specimens of this remarkably beautiful eel were secured in the market at Naha.

\section{ECHIDNA NEBULOSA (Ahl).}

ECHIDNA KISHINOUYEI Jordan and Snyder.

The writer can not follow Jordan and Seale in identifying this species with E. delicatula (Kaup) if the species described by Bleeker ${ }^{2}$ is identical with that represented by Kaup's specimen. The type of E. kishinouyei came from Okinawa. A second specimen from the Naha market does not differ from the type. These have the body, including the head, much shorter than the tail, and they differ in other particulars from E. delicatula as will appear when Bleeker's description is compared with the following:

Head 3 in trunk, 10 in total length; head and trunk 1.5 in tail; eye 14 in head; snout 7 . Dorsal inserted midway between gill opening

${ }^{2}$ Atl. Ichth. Muræn., p. 78, pl. 23, fig. 3. 
and tip of snout. Mouth small, the eye on a vertical passing midway between tip of snout and angle of mouth. In the upper jaw the teeth are in a single series anteriorly, in 3 series posteriorly; all bluntly pointed, the anterior ones very heavy and slightly curved backwards, the posterior ones somewhat more slender; anterior part of jaw with 2 or more rather large median teeth behind which is a vomerine series, forked in front. Teeth of lower jaw heavy and rather blunt, in 2 series laterally, but increasing in number and forming a cluster at the symphysis. Body gray, mottled and spotted with brown, the head on anterior half plain brown; gill opening with a brown spot. The type is much faded and therefore lighter, the markings being less distinct. The fins are like the body, the tip of the tail dark. The length of the specimen here described is 145 millimeters.

ECHIDNA POLYZONA (Richardson).

A specimen from the tide pools, 130 millimeters long, was brownish black in life with narrow bars of yellowish white.

$$
\text { Family BELONIDÆ. }
$$

TYLOSURUS GIGANTEUS (Temminck and Schlegel).

\section{Family EXOCCETIDÆ. ${ }^{1}$}

HEMIRAMPHUS, sp.

Some badly damaged specimens from the market that closely resemble $H$. pacificus, may possibly belong to that species.

HEMIRAMPHUS COMMERSONI Cuvier.

One specimen 380 millimeters long from the market has the fourth spot of the body located below the middle of the dorsal fin. A fifth faintly outlined spot is below the posterior part of the dorsal. There extends along the dorsal part of the body a conspicuous stripe which, below the dorsal fin, is equal in width to one scale. Anteriorly the stripe broadens toward the pectoral; posteriorly it narrows on the caudal peduncle and then abruptly widens on the base of the caudal fin. The dorsal part of the stripe is steel blue, the ventral part silvery. The dorsal has 12 rays, the anal 10. There are 50 scales in a lateral series.

PAREXOCGTUS BRACHYPTERUS (Solander).

Family FISTULARIIDE。

FISTULARIA PETIMBA Lacépède.

FISTULARIA SERRATA Cuvier.

Family SYNGNATHIDÆ.

CORYTHROICHTHYS ISHIGAKIUS (Jordan and Snyder).

Nine specimens were taken in the tide pools. The length of the snout usually equals that of the rest of the head, but in some examples 
it is slightly less while in others it is considerably more. In some individuals the dark throat bars are little developed or even absent.

The writer is unable to find any characters that will distinguish the recently described $C$. waitei or $C$. elerae from this species.

MICROPHIS EXTENSUS Snyder.

Plate 62, fig. 2.

Microphis extensus SNyder, Proc. U. S. Nat. Mus., vol. 40, 1912, p. 525.

Pools at Naha.

ICHTHYOCAMPUS NOX Snyder.

Plate 62, fig. 3.

Ichthyocampus nox SNYder, Proc. U. S. Nat. Mus., vol. 36, 1909, p. 598.

One specimen, a female, from a pool at Naha.

MICROPHIS OCELLATUS Snyder.

Plate 63, fig. 1.

Microphis ocellatus Snyder, Proc. U. S. Nat. Mus., vol. 36, 1909, p. 598.

Pools at Naha.

\section{Family MUGILIDA.}

MUGIL CEPHALUS Linnæus.

LIZA TROSCHELI (Bleeker).

Family SPHYRAENIDA.

SPHYRAENA OBTUSATA Cuvier and Valenciennes.

Two specimens from the market agree in appearance with one figured by Günther in his Fische der Südsee.

SPHYRANA COMMERSONI Cuvier and Valenciennes.

Family POLYNEMIDAE.

POLYDACTYLUS AGONASI Jordan and McGregor.

Family HOLOCENTRID ${ }^{1}{ }^{1}$

MYRIPRISTIS INTERMEDIUS (Günther).

One specimen about 230 millimeters long, from the market, has the tip of the dorsal lightly touched with dusky color, and a mere trace of black on the anal. Both the soft dorsal and anal are narrowly edged with white.

\section{MYRIPRISTIS MACROLEPIS Bleeker.}

An individual from the market agrees closely with Bleeker's figure except in color. It has in addition to the dark border of the opercular membrane, a black tipped dorsal, anal, and caudal. The scales of the back are narrowly edged with dusky color. It is like a specimen 
from Bacon, Philippine Islands, except that the latter has immaculate fins. This species may be distinguished from $M$. adustus by its more rounded head and less conical snout.

HOLOCENTRUS SAMMARA (Forskål).

One specimen from the market. The soft dorsal is narrowly edged with dusky color. The third anal spine and the first ray are dark.

HOLOCENTRUS BINOTATUS Quoy and Gaimard.

Two examples measuring about 280 millimeters, from the market, agree with Samoan specimens except that they have no dark marks on the dorsal membrane.

HOLOCENTRUS RUBER (Forskål).

A specimen 210 millimeters long, purchased in the market, is: in every particular like the figure of $H$. melanospilus of Bleeker. ${ }^{1}$ It has a somewhat more elongate snout and longer and more pointed ventrals than an example from Hongkong figured by Jordan and Seale. ${ }^{2}$ The spot at the bases of the dorsal, anal, and caudal are very conspicuous on the Okinawa specimen.

HOLOCENTRUS PUNCTATISSIMUS Cuvier and Valenciennes.

One small example from the pools.

\section{Family SCOMBRID丑.}

EUTHYNNUS ALLETERATUS (Rafinesque).

A specimen from the market, with 6 spots below the corslet, has been identified as $E$. alleteratus without direct comparison with specimens from elsewhere.

\section{Family CARANGID疋. ${ }^{3}$}

SCOMBEROIDES SANCTIPETRI Cuvier and Valenciennes.

TRACHUROPS CRUMENOPHITRALMA (Bloch).

CARANX JARRA Cuvier and Valenciennes.

CARANX IGNOBILISS (Forskål).

CARANX FORSTERI Cuvier and Valenciennes.

ILECTIS CILIARIS (Bloch).

Differs from $A$. major in the heavier body, broader interorbital space, and darker colored dorsal area.

\section{Family TRICHIURID珑.}

TRICHIURUS HAUMELA (Forskål).

There are 2 orange stripes along the sides, the lower bordering the lateral line. 


\section{Family PEMPHERIDA.}

PEMPHERIS JAPONICUS Doderlein.

PEMPHERIS OUALENSIS Cuvier and Valenciennes.

\section{- Family CHILODIPTERIDA.}

AMIA NOVEMFASCIATA (Cuvier and Valenciennes).

This species is abundantly represented in the pools. In life the body above the median stripe has a distinctly bluish sheen, while below it is reddish; stripes brassy, the two dorsal ones tinged with olive; edge of opercle bluish; iris brassy; spinous dorsal suffused with dark orange, other fins with light red, the soft dorsal having a brassy bar.

AMIA SAVAYENSIS (Gtinther).

Small specimens were occasionally seen in the tide pools.

AMIA LATERALIS (Valenciennes).

Market. Four individuals measuring about 65 millimeters, show traces of a short stripe above the median one.

AMIA ERYTHRINA (Snyder).

Apparently rare, but one example having been seen in the pools.

APOGONICHTHYS NAFæ Snyder.

Plate 63, fig. 2.

Apogonichthys nafx, SNyder, Proc. U. S. Nat. Mus., vol. 36, 1909, p. 599.

Naha pools.

Family KUHLIIDA.

SAFOLE T EENIURA (Cuvier and Valenciennes).

\section{Family SERRANID无. ${ }^{1}$}

\section{VARIOLA LOUTI (Forskå1).}

Of two specimens secured in the market, the larger, measuring 330 millimeters in length, was colored as follows: Yellowish olive above, shading into salmon red beneath, each scale with a darker center; head, body, and fins with spots which are cerulean blue on the upper parts, reddish on the sides, and decidedly red beneath, each spot with a narrow, dark blue margin; posterior border of dorsal, anal, caudal, and pectorals with a broad margin of orange, the terminal margin of the pectoral bordered proximally with bluish gray; outer edges of ventrals reddish brown, the inner edges orange. In alcohol the color is dark, the dorsal spots bluish gray, the ventrals white; fins with the posterior edges white. The smaller example, 150 millimeters in length, is almost devoid of color, the light borders of the spots and fins being scarcely distinguishable in consequence. 


\section{VARIOLA FLAVIMARGINATA (Rüppell):}

CEPHALOPHOLIS URODELUS (Forster).

Several specimens from the market show a considerable amount of variation in color. Two are almost black, except for light, convergent caudal stripes which are separated by jet black areas. A third specimen has only the tail and caudal fin of a dusky hue, while a fourth is almost entirely without dark color, the caudal stripes being very faint. The darkest example has a dusky opercular spot, and all have black-edged ventrals.

One small specimen was taken in a tide pool.

CEPHALOPHALUS SONNERATI (Cuvier and Valenciennes).

One example from the market measures 300 millimeters in length. The second anal spine is slightly shorter and heavier than the third. The fins, except the pectorals, have narrow dusky borders, the dorsal, anal, and caudal being edged with white.

EPINEPHELUS MEGACHIR (Richardson).

Many were seen in the market, and a few were taken in the pools.

EPINEPHELUS STELLATUS (Richardson).

Collected from both the market and pools.

EPINEPHELUS TSIRIMENARA (Temminck and Schlegel).

Market specimens were light crimson,each scale with a lighter center; spinous dorsal with a black margin, the other fins with yellowish margins.

EPINEPHELUS TAUVINA (Forskål).

EPINEPHELUS CARULEOPUNCTATUS (Bloch).

One small example from a tide pool.

EPINEPHELUS SUMMANA (Forskål).

One very dark specimen, the light spots of the body being very indistinct, while those of the fins are more prominent.

EPINEPHELUS RHYNCHOLEPIS Bleeker.

Small, pearly spots, prominent in examples from the market, have almost entirely disappeared in the preserved specimens.

PLESIOPS MELAS (Bleeker).

This species is abundantly represented in the pools. In life the body is deep brownish black, the color a little lighter on basal parts of scales; iris blue and gold; dorsal spines tipped with bright reddish orange, a narrow, purple stripe extending along middle of fin, the membrane of soft dorsal dark yellowish gray below the stripe; pectoral tinged with yellow; anal with an indistinct, narrow, pearly blue stripe passing diagonally from base of first spine to tip of last ray. In alcohol the specimen here described has become brownish black, the spinous dorsal being tipped with white. 
Family LUTIANID E. $^{1}$

LUTIANUS KASMIRA (Forskål).

Two specimens from the market, 70 millimeters long, have the oblique stripes rather faintly outlined, while a conspicuous, dark spot appears below the origin of the soft dorsal, and between the stripes which pass backward from the eye. One large example has the stripes well defined and the spot scarcely discernible.

LUTIANUS RIVULATUS (Cuvier and Valenciennes).

Some market specimens about 80 millimeters long are presumed to be young individuals of this species. They have a well-defined dark bar extending from the base of the pectoral to the origin of the dorsal, behind which are one or two indistinctly outlined or scarcely visible bars. A white spot on the lateral line is bordered anteriorly and posteriorly by a dark spot. There are narrow, dark bars across the interorbital space.

\section{LUTIANUS QUINQUELINEATUS (Bloch).}

LUTIANUS ARGENTIMACULATUS (Forskål).

LUTIANUS VITTA (Quoy and Gaimard).

Color of a fresh market specimen, grayish olive, slightly darker above the lateral line where the body color becomes decidedly tinged with yellow posteriorly; lighter below lateral line, the ventral surface suffused with light red; many oblique, yellow stripes above lateral line; each scale below lateral line with a narrow, greenish white stripe; those on ventral surface pearly; between the narrow stripes are broader ones of pale orange; head grayish olive above, the sides strongly tinged with lavendar; maxillary, edge of lower jaw and lower edge of preopercle margined with yellow; chin, throat, and branchiostegal region dead white; dorsal fins tinged with yellowish olive and edged with orange; pectorals and ventrals suffused with orange; spot below origin of soft dorsal brownish black; a pale, scarcely visible dark stripe passing from snout through eye toward dark spot.

LUTIANUS MONOSTIGMA (Cuvier and Valenciennes).

APRION VIRESCENS (Cuvier and Valenciennes).

PLATYINIUS AMGENUS Snyder.

Plate 63, figure 3.

Platyinius amœnus Snyder, Proc. U. S. Nat. Mus., vol. 40, 1912, p. 530.

Family HAMULIDA.

CEESIO ERYTHROGASTER Cuvier and Valenciennes.

CAESIO CAERULAUREUS (Lacépède).

CAESIO CHRYSOZONUS Kuhl and Van Hasselt.

Color of a market specimen, deep purple above, becoming bluish on the sides; ventral surface pearly blue, each scale with an indistinct 
reddish spot; chin and throat suffused with bright red; two narrow, bright orange stripes on the dorso-lateral surface; fins strongly suffused with pink; caudal lobes tipped with black; axil of pectoral black.

TERAPON JARBUA (Forskål).

PLECTORHYNCHUS DIAGRAMMA (Lacépède).

Of two specimens procured in the market, one has the membrane of the spinous dorsal black, the soft dorsal with two rows of round black spots and a black edge, the caudal with large, round black spots and a black edge, the anal similar, and the pectorals dusky. The other has the dorsals and anal narrowly edged with black, the spinous dorsal with a median row of black spots, the soft dorsal with oblique, dark bars which tend to break up into spots, the caudal and anal with black spots, and the pectoral dusky. The edges of the ventrals in each case are broadly bordered by dusky color on the upper surface, the membranes of the fins being dead white between the rays.

\section{PLECTORHYNCHUS CHATODONTOIDES (Lacépède).}

In a fresh market specimen the spots of the body are deep brown, the interspaces light yellowish gray; ventral parts gray, with pearly reflections; fins tinged with pearly blue; lips white, the membrane behind upper lip bright red; inside of mouth clouded with red.

\section{POMADASIS ARGENTEUS (Lacêpède).}

POMADASIS HASTA (Bloch).

Rows of small, dusky spots along the sides above the median line, which do not tend to form vertical bars or series.

\section{SCOLOPSIS CANCELLATA Cuvier and Valenciennes).}

SCOLOPSIS BILINEATA (Bloch).

Bloch says: "Le Japon producit ce poisson", and the finding of 3 examples in the Naha market tends to support the statement.

PENTAPUS MICRODON (Bleeker).

One specimen from the market agrees with Bleeker's figure and description.

PENTAPUS FORMOSULUS Snyder.

Plate 64, fig. 1.

Pentapus formosulus Snyder, Proc. U. S. Nat. Mus., vol. 40, 1912, p. 531.

There are 48 scales in the lateral series.

GNATHODENTEX AUROLINEATUS (Lacépède).

$$
\text { Family SPARIDA. }
$$

LETHRINUS HARAK (Forskål).

LETHRINUS RICHARDSONI Ginther.

LETHRINUS AMBOINENSIS Bleeker.

LETHRINUS MOENSI Bleeker.

PAGRUS CARDINALIS (Lacépède).

SPARUS SCHLEGELI (Bleeker). 


\section{Family KYPHOSID瓜.}

GIRELLA MEZINA Jordan and Starks.

Two specimens from the market and one from a tide pool. The vertical band is scarcely visible on one and entirely absent from another, the smallest one, which measures about 500 millimeters in length.

\section{Family GERRIDÆ.}

GERRES FILAMENTOSUS Cuvier and Valenciennes.

\section{Family OPLEGNATHIDE.}

OPLEGNATHUS FASCIATUS (Temminck and Schleget).

Three specimens from the tide pools.

\section{Family MULLID瓜.}

UPENEUS MOANA Jordan and Seale.

In some examples the color is very pale, only the two posterior dark saddles appearing distinctly, the others being barely suggested.

UPENEUS BARBERINUS (Lacépède).

UPENEUS BARBERINOIDES Bleeker.

In 3 specimens the dusky color of the sides extends well on to the ventral surface, the pectoral has a conspicuous splash of dusky at its base, and the lower caudal lobe is broadly bordered with blackish.

UPENEUS PLEUROTANIA (Playfair).

A single specimen obtained in the Naha market is certainly a representative of this species, agreeing perfectly with the description of Playfair. ${ }^{1}$

The head is contained 3.4 times in the length; depth equal to length of head; eye 2 in snout, 4.5 in head; scales in lateral line 29; between lateral line and dorsal 2 ; between lateral line and base of anal 6 . The barbels reach a vertical through posterior edge of preopercle. Gill-rakers about 6-22, those of lower arch long and slender. The dorsal spines and rays are not filamentous, the spinous dorsal when depressed falling far short of the base of soft dorsal.

In life, the scales of the upper parts are narrowly margined with olive, while ventrally the marginal color fades and becomes tinged with red; there is a white saddle across caudal peduncle at base of soft dorsal; sides with three white stripes, the first or upper extending from eye in almost a straight line to end of soft dorsal fin, the second from tip of snout through lower edge of eye to light saddle on caudal peduncle, the third may be traced for a short distance along the row of scales below the latter; barbels yellow; spinous dorsal clouded with greenish yellow and white, pinkish toward the edge; soft dorsal and

1 Fishes of Zanzibar, p. 41, fig. 3, not 4, the reference numbers evidently having been interchanged. 
anal yellowish with pearly white spots; pectorals. ventrals, and caudal suffused with pink.

In spirits the posterior light saddle and the two upper stripes remain perfectly distinct.

\section{UPENEUS CYCLOSTOMUS (Lacépède).}

\section{UPENEUS CHRYSERYDROS (Lacépède).}

UPENEUS PLEUROSPILOS Bleeker.

Three examples of this species were secured. The black lateral spot does not seem to be a constant character, perhaps disappearing with age. It is distinct in a specimen 150 millimeters long, scarcely visible in one 240 , and entirely absent in a larger example.

Head 3.5 in length to base of dorsal; depth, 3.5 ; depth caudal peduncle, 9.2 ; eye, 4.7 in head; width, interorbital space, 3.5 ; length snout, 1.9 ; maxillary, 2.4 ; D. VIII, 9 ; A. 7 ; scales in lateral line 29.

Body rather deep, the contour rising gradually from tip of snout to origin of spinous dorsal. Eye nearer border of opercle than tip of snout a distance equal to its diameter. Interorbital space high and strongly convex, this character becoming more pronounced with age. Maxillary not reaching a vertical through anterior edge of orbit, its upper edge fitting beneath edge of preorbital, the posterior edge rounded. Barbels reaching a vertical through edge of opercle. Gill-rakers 6-17; those on lower arch long and slender. Teeth in a single series on jaws, strong and rather short. Scales weakly ctenoid. First dorsal spine minute, the third longest, 1.5 in head; spines when depressed not reaching base of second dorsal. Second dorsal low, the longest (second) ray about equal to depth of caudal peduncle; anal slightly higher. Caudal deeply forked, 1.2 in head; pectorals 1.4; ventrals 1.4.

Color in spirits: Opercle dark, the dusky lining of the inside showing through; a faint dark spot below lateral line at a point beneath posterior portion of spinous dorsal; absent on large individuals; scales of upper part of body narrowly edged with darker, the center having a somewhat lighter area.

\section{UPENEUS INDICUS (Shaw).}

Color in life: Body above lateral line suffused with purple, slightly greenish gray below, the light spot between the dorsals with a brassy sheen; scales on upper parts narrowly edged with yellowish olive, the color fading and almost disappearing ventrally; each scale of lower parts with a pale brassy spot on its posterior edge; caudal peduncle with narrow yellowish stripes in region of the black spot, the body color here being almost white; head colored like the body; a pearly blue stripe from tip of snout to lower margin of eye; snout with vermiculations of same color; vermiculations and line followed by narrow yellow stripes; barbels white; spinous dorsal pinkish, the membrane anterior to each spine greenish yellow, soft dorsal pinkish 
with greenish yellow oblique bars; anal pearly white with oblique yellow bars; caudal reddish, the membranes suffused with greenish yellow; pectorals suffused with cherry red.

\section{UPENEUS PLEUROSTIGMA (Bennett).}

Color in life: Bright red above growing lighter and tinged with red on the sides; white beneath; head reddish above, the sides with bluish reflections, purple striles extending forward from eye; barbels tinged with pink; spines of dorsal red, the membranes suffused with yellowish red; soft dorsal reddish on basal half, the upper part with yellow and pearly stripes, the latter bordered with reddish; upper and lower lobes of caudal red, the middle rays bright yellow; anal pale pearly blue, with yellow stripes.

MULLOIDES FLAVOLINEATUS (Lacépède).

A single specimen 290 millimeters Jong is referred to this species.

Head 3.5 in the length; depth 3.8 ; snout 2.2 in the head; eye 4.2; scales in lateral line 39 , the pores with many branches; gill-rakers $7-20$ on first arch, the longest not equal in length to diameter of pupil; barbels reaching to below posterior border of opercle; dorsal spines $7 ; 4$ scales between tips of depressed spines and base of soft dorsal; 8 dorsal and 6 anal rays.

In life the head and body were strongly suffused with pearly blue above the lateral line, pink below; a dark lemon yellow stripe extended from eye to caudal fin, crossing the lateral line at a point below last dorsal ray; each scale above stripe bordered by yellowish olive, below with deep pink; head reddish, darker above; iris silvery, a conspicuous red ring around pupil; barbels whitish; pectorals suffused with reddish, the other fins bright yellow.

UPENEOIDES BEINSASI (Temminck and Schlegel).

This species, somewhat resembling $U$. vittatus in its color pattern, may be distinguished by the long first dorsal spine.

UPENEOIDES TRAGULUS (Richardson).

In life, greenish gray, lighter below; a broad brown lateral stripe extending from eye to caudal fin, below which the head and body are spotted with brown; barbels orange; spinous dorsal clouded with brown, purple and lemon yellow; soft dorsal spotted with reddish brown, the membrane suffused with yellow; caudal lightly washed with yellow, barred with brownish black; ventrals and anal tinged with yellow and spotted with pale purplish brown; pectoral yellowish, spotted with reddish brown.

UPENEOIDES VITTATUS (Forskål).

Color in life, silvery, the upper parts with a pale greenish sheen, the ventral surface pale yellow; sides with 4 metallic stripes, the upper 2 dark copper colored, the next lower brassy, and the lowest 
somewhat lighter; spinous dorsal edged with black, the median portion with 2 dead white bars between which is one of brassy; soft dorsal without black, but otherwise colored as the spinous portion; caudal with black bars having a brassy sheen; ventrals and anal dead white, tinged with yellow; pectorals transparent; barbels white.

\section{Family POMACENTRID王.}

\section{AMPHRIPRION FRENATUS Brevoort.}

In life the color is brilliant red tinged with orange, deeper on the snout, lighter posteriorly; tips of soft dorsal, caudal and anal deep orange; bar of head cerulean blue, bordered by deeper blue, the whole edged with brownish black, the dark color spreading anteriorly and posteriorly into a cloud which extends from eye to end of spinous dorsal; pectoral light reddish orange; ventrals similar, the spine brownish black.

POMACENTRUS NIGRICANS Lacépède.

POMACENTRUS MELANOPTERUS Bleeker. .

POMACENTRUS DORSALIS Gill.

The synonomy adopted by Jordan and Snyder ${ }^{1}$ for a species, $P$. dorsalis, described by Gill, ${ }^{2}$ may also include $P$. delurus Jordan and Seale. $^{3}$ Several specimens agreeing almost perfectly with Dr. Theodore Gill's description and also with a cotype of $P$. delurus were collected in the pools at Naha. The spot at base of pectoral mentioned by Gill is scarcely discernible and the posterior bluish spots are faint. The cotype of $P$. delurus has 15 rays in the dorsal, the spot on the soft dorsal is not ocellate, but has only a light border anteriorly; the scales in the lateral line number 25 or 26 .

ABUDEFDUF SORDIDUS (Forskål).

Common in the pools.

ABUDEFDUF RICHARDSONI Snyder.

Plate 64, fig. 2.

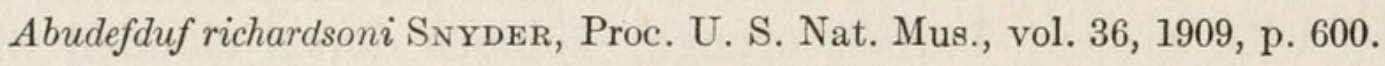

Pools near Naha.

ABUDEFDUF REX Snyder.

Plate 64, fig. 3.

Abudefduf rex SNyder, Proc. U. S. Nat. Mus., vol. 36, 1909, p. 601.

Tide pools, Naha. 
ABUDEFDUF ZONATUS (Cuvier and Valenciennes).

Apparently rather rare in the pools. Brownish black in life, with a bluish white bar across median part of body; scales posterior to bar with purple centers, those anterior being similar but lighter; fins slightly tinged with olive; a small black spot on upper edge of base of pectoral. Small examples (400 millimeters long) have a black ocellus near end of spinous dorsal and a black spot on upper part of caudal peduncle just behind base of soft dorsal.

ABUDEFDUF GLAUCUS (Cuvier and Valenciennes).

This species may be recognized at once among the other blue tide-pool fishes of Okinawa by the jet black anal opening.

ABUDEFDUF TURCHESIUS Jordan and Seale.

In life, bright cerulean blue with black markings on throat and breast. The smaller examples have a more or less definite black spot on body at base of last dorsal ray. The color fades rapidly as the fish dies, the body becoming dark, each scale with a dusky edge, the throat growing yellowish.

Specimens are very abundant in the pools.

ABUDEFDUF CELESTINUS (Cuvier and Valenciennes).

Large examples were seen in the market, and a few young individuals were collected from the pools. They agree in all details with Samoan specimens.

ABUDEFDUF RHOMALEUS Snyder.

Plate 65, fig. 1.

Abudefduf rhomaleus SNYder, Proc. U. S. Nat. Mus., vol. 40, 1912, p. 534.

Family MALACANTHIDA.

MALACANTHUS PARVIPINNIS (Vaillant and Sauvage).

OCEANOPS LATOVITTATA (Lacépède).

Family PSEUDOCHROMIDÆ.

DAMPIERIA SPILOPTERA (Bleeker).

This species is rather common in the pools.

Family CIRRHITIDÆ.

GONIISTIUS ZEBRA (Döderlein).

This species differs in color from G. vittatus of Hawaii; the body is not so deep and the profile above the eyes is much less gibbous.

PARACIRRHITES FORSTERI (Bloch and Schneider).

Several specimens were found in the market. 


\section{Family LABRID L. $^{1}$}

CHERODON JORDANI (Snyder).

Plate 65, fig. 2.

Chœrops jordani SNyder, Proc. U. S. Nat Mus., vol. 35, 1909, p. 98.

LEPIDAPLOIS LOXOZONUS Snyder.

Lepidaplois loxozonus SNyder, Proc. U. S. Nat. Mus., vol. 35, 1909, p. 94.

LEPIDAPLOIS MIRABILIS Snyder.

Plate 66, fig. 1.

Lepidaplois mirabilis SNyder, Proc. U. S. Nat. Mus., vol. 35, 1909, p. 96.

LEPIDAPLOIS PERDITIO (Quoy and Gaimard).

EPIBULUS INSIDIATOR (Pallas).

A fresh market specimen was bright orange, each scale having a narrow, vertical, brownish bar; dorsal with a median orange stripe, above which the membrane is suffused with green; a barely discernable brownish stripe extending through eye toward upper edge of gill opening. The same specimen, measuring 210 millimeters in length, when placed in alcohol became plain yellowish relieved by a dusky bar on the head and a few faint dark spots on the scales. A larger preserved specimen is very dark in color, the fins being almost black. The pectoral has a distinct light border and the scales have dark borders except in the region immediately above and behind the pectorals, where they are much lighter. The dark stripe on the head is very conspicuous..

HEMIGYMNUS FULIGINOSUS (Lacépède).

ANAMPSES CAERULEOPUNCTATUS Rüppell.

STETHOJULIS CASTURI Günther.

STETHOJULIS PHEKADOPLURA Bleeker.

One very small specimen from the pools is referred with some doubt to this species.

STETHOJULIS AXILLARIS Quoy and Gaimard.

Four specimens, measuring about 700 millimeters long, from the pools are identified with the Hawaiian S. axillaris, for when directly compared they resemble specimens from Honolulu very closely. It is probable that this species and $S$. bandanensis (Bleeker) are synonymous. In alcohol the Okinawa specimens are not abruptly lighter below as are examples of $S$. bandanensis from Samoa described by Jordan and Seale, but on the contrary the dark color of the upper 
parts is maintained almost to the ventral surface, where the transition to a lighter hue is gradual. In life the color is more like that presumed to be characteristic of $S$. bandanensis. Brown above median line with minute blue spots; scales below median line edged with bluish white, their centers bluish gray, becoming lighter on belly and blue posteriorly; chin and throat pearly white; a narrow blue stripe beneath eye, below which is a broad orange band; a bright orange spot above axil, below which is a line of black and then a cerulean blue spot; dorsal, caudal, and basal part of anal tinged with reddish orange, the edge of anal bluish.

STETHOJULIS STRIGIVENTER (Bennett).

Rather common in the pools. The young of this species measuring 70 millimeters or less in length do not have the posterior canines present.

Color in life: Body olive above, silvery below, bluish on breast and belly, rather purplish on lower part of head; a pearly blue line below eye bordered by brown; lines on sides silver and olive; dorsal pale orange, narrowly edged with pearly white, the ocellus surrounded by transparent membrane; middle of caudal suffused with orange, the outer rays tinted with blue; anal like dorsal; pectorals pink; ventrals bluish.

PLATYGLOSSUS NOTOPSIS (Kuhl and Van Hasselt).

Apparently rare in the pools. The young are brownish black; ocellus on dorsal dead black bordered by orange; a stripe along side, running from snout below eye and extending toward caudal (in many examples broken into spots posteriorly) and 2 shorter stripes below it, pearly blue; 2 lines above the median one, greenish yellow; caudal greenish yellow.

\section{HALICHERES OPERCULARIS (Guinther).}

Occasionally seen in the pools. In life the body is silvery with a greenish cast, most of the scales edged with brick red or reddish brown, the dorsal ones darker where the reddish color nearly covers the scales; a small blackish spot behind eye, another on opercle, 2 or 3 near center of body and another on caudal peduncle; a pale golden stripe bordered by greenish blue below the eye, and a greenish stripe on snout before eye; dorsals with rather irregular vertical or oblique bands of red bordered by dusky, the membrane of fin tinged with golden; ocellus on soft dorsal black, the ring colorless below, orange above; median rays of caudal dotted with red, the fin narrowly edged with red; anal greenish yellow with red bands; pectorals suffused with pink; ventrals deep red at base, broadly edged with dead white.

CORIS ANNULATA (Lacépède).

Two specimens from the market measuring 270-310 millimeters in length. 
CORIS VARIEGATA (Rüppell).

JULIS PULCHERRIMA (Günther).

A market specimen measuring 250 millimeters, 68 scales. The color pattern closely resembles that of the example figured by Jordan and Evermann, Fishes of Hawaii.

\section{CHEILIO INERMIS (Forskål).}

THALASSOMA JANSENI (Bleeker).

In examples from the market, 110 to 190 milimeters long, there are some with three distinct dark bands, others in which the bands blend somewhat on the sides, and an occasional specimen where they are entirely confluent, the upper part of body being largely black from snout to end of caudal fin; caudal peduncle light in all cases.

THALASSOMA UMBROSTIGMA (Rüppell).

THALASSOMA GUNTHERI (Bleeker).

THALASSOMA AMBLYCEPHALUS (Bleeker).

Eight specimens collected from the pools.

THALASSOMA LUTESCENS (Solander).

A large series of T. lutescens, both male and female, together with color notes made in the field show beyond doubt that Thatassoma neanis Jordan and Evermann ${ }^{1}$ is a male example of T. Tutescens. While the color of the males of this species is exactly like that described for $T$. neanis, the females are much plainer, the dark bars on the scales being more prominent. In some examples these bars become elongate, and almost uniting give the appearance of vertical lines on the sides. Some males have the superior and inferior caudal rays greatly broadened and lengthened.

THALASSOMA DORSALE (Quoy and Gaimard).

The upper part of opercle has a small round patch of scales.

\section{CHEILINUS FASCIATUS (Bloch).}

One specimen has the lateral bands very weak, there being but 2 or 3 series of elongate dusky spots on the scales.

CHEILINUS DIAGRAMMUS (Lacêpède).

One example from the market is like specimens from Samoa in every detail except that there are no spots or stripes of any color on the head.

\section{CHEILINUS TRILOBATUS Lacépède.}

NOVACULICHTHYS TÆNIURUS (Lacêpède).

NOVACULICHTHYS MACROLEPIDOTUS (Bloch).

INIISTIUS DEA (Temminck and Schlegel).

There are a few small scales behind the eye and at the upper edge of opercle. 
THALLIURUS CHLORURUS (Bloch).

The upper and lower caudal lobes are considerably produced. The upper lips are frilled within, the innermost frill being conspicuously beaded or notched along the edge.

\section{Family SCARICHTHYIDÆ. ${ }^{1}$}

CALLYODON MAORICUS (Jordan and Seale).

Two specimens from the Naha market agree in all details with a cotype of the species. Both differ from the description, however, in having the dorsal VIII, 11, and the eye 7 in head. The posterior edge of the caudal varies from slightly convex to concave.

CALLYODON PRASIOGNATHUS (Cuvier and Valenciennes).

CALLYODON PYRRHOSTETHUS (Richardson).

CALLYODON RIVULATUS (Cuvier and Valenciennes).

CALLYODON LUNULA Snyder.

$$
\text { Plate 66, fig. } 2 .
$$

Callyodon lunula Snyder, Proc. U. S. Nat. Mus., vol. 35. 1909, p. 99.

CALLYODON BOWERSI Snyder.

Plate 66, fig. 3.

Callyodon bowersi SNyder, Proc. U. S. Nat. Mus., vol. 36, 1909, p. 602.

CALLYODON GEDEMA Snyder.

\section{Plate 67, fig. 1.}

Callyodon œdema Snyder, Proc. U. S. Nat. Mus., vol. 36, 1909, p. 603.

CALLYODON BALINENSIS (Bleeker).

CALLYODON BICOLOR (Rüppell).

One specimen from the market, measuring about 300 millimeters in length agrees with Bleeker's figure and description, ${ }^{2}$ except that many of the spots on the sides are prolonged into vertical bands, and numerous scales have both a band and a spot. The nostril tentacle is very prominent as noted by Bleeker.

CALLYODON FORSTENI (Bleeker).

A single example of this species from the Naha market agrees perfectly with the description and figure given by Bleeker. ${ }^{3}$

\section{Family PLATACIDÆ.}

PLATAX TEIRA (Forskål).

Some of the teeth have the cusps of equal size while others have the median one largest, in some cases excessively long. There are no vomerine teeth.

Idem, p. 38, pl. 2. 


\section{Family CHÆTODONTIDE. ${ }^{1}$}

CHATTODON SETIFER Forskål.

Many seen in the market. One specimen caught in a tide pool.

CHETODON VAGABUNDUS Linnæus.

Two small specimens were secured from a pool.

CHETODON ULIETENSIS Cuvier and Valenciennes.

CHETODON LUNULA (Lacépède).

Small specimens were occasionally seen in the pools.

CHETODON CITRINELLUS (Broussonet).

CHETODON TRIFASCIATUS Park.

CHAETODON ORNATISSIMUS (Solander).

MEGAPROTODON TRIFASCIALIS (Quoy and Gaimard).

HANIOCHUS ACUMINATUS (Linnæus).

HOLACANTHUS LEPIDOLEPIS (Bleeker).

MICROCANTHUS STRIGATUS (Cuvier and Valenciennes).

HOLACANTHUS BISHOPI Seale.

Five small specimens from the pools, measuring 24 to 43 millimeters in length agree almost perfectly with the description of this species, there being however, no white circle in front of the caudal peduncle, and in addition to other light bands on the head, there is a median line extending from tip of snout to occiput.

The curved bands are all pearly white in life, becoming purple at their narrowest places. The narrow bands are mostly purple, the broad ones mostly white. The body color is a uniform blue black.

\section{Family ACANTHURID . $^{2}$}

HEPATUS OLIVACEUS (Bloch and Schneider).

HEPATUS MATOIDES (Cuvier and Valenciennes).

HEPATUS TRIOSTEGUS (LinnæUS).

Many specimens were seen in the market and four small ones were secured in the pools.

HEPATUS DUSSUMIERI (Cuvier and Valenciennes).

MONOCEROS UNICORNIS (Forskål).

MONOCEROS TUBEROSUS (Lacépède).

A single specimen agrees perfectly with the description and figure of Naseus punctulatus Steindachner. ${ }^{3}$

MONOCEROS BREVIROSTRIS (Cuvier and Valenciennes).

1 Chætodon dædalma (Jordan and Fowler). Holacanthus tibicen (Cuvier and Valenciennes).

${ }^{2}$ Hepatus elongatus (Laéepède). Zebrasoma flavescens (Bennett).

${ }^{3}$ Ichth. Beitr., 1874, p. 12, fig. 8. 


\section{Family SIGANID $Æ$.}

SIGANUS MARMORATUS (Quoy and Gaimard).

Market and pools. One specimen exhibits a type of coloration much like that figured by Day, ${ }^{1}$ except that the pearly lines of the fresh specimen have become brown in the preservative. In the region of the pectoral the lines are vertical.

SIGANUS LINEATUS (Cuvier and Valenciennes).

In a fresh market specimen the color was brownish above and lighter below; upper parts with many brassy spots which are bordered with olive; a large lemon yellow spot below soft dorsal; region bordering base of anal yellow; sides of head with brassy lines; dorsal dusky suffused with yellow; caudal dusky, with dark spots arranged in vertical rows; spines of anal lemon yellow, rays pearly blue, the membranes dusky, suffused with yellow; rays of ventrals yellow; pectorals uncolored. The example described measured 230 millimeters.

The preserved specimens show no trace of the bright colors of life except a mottling on the upper parts and some traces of bars on the caudal.

SIGANUS FUSCESCENS (Houttuyn).

SIGANUS ROSTRATUS (Cuvier and Valenciennes).

One small specimen referred to this species was taken in a pool.

SIGANUS CORALLINUS (Cuvier and Valenciennes).

SIGANUS PUNCTATUS (Bloch and Schneider).

SIGANUS VIRGATUS (Cuvier and Valenciennes).

SIGANUS TETRAZONUS (Bleeker).

Many specimens measuring about 600 millimeters in length were collected from the pools. In some examples there are 4 or 5 rather poorly defined bars across the back, each connecting with a spot on the dorsal, while in others the bars are very indistinct or entirely wanting.

\section{Family BALISTIDÆ. ${ }^{2}$}

\section{BALISTES NIGER Bonnaterre.}

\section{BALISTES VIDUA Richardson.}

BALISTES FUSCUS Bloch and Schneider.

The single specimen obtained has 3 distinct and widely spaced rows of plates on the cheek, below which is one or more closely apposed to the scales of the throat and chin.

${ }^{1}$ Fishes, India, pl. 40, fig. 2.

2 Balistes capistratus (Shaw).

Balistes flavimarginatus (Rüppell). 
BALISTES CHRYSOPTERUS Bloch and Schneider.

Three specimens were taken in a large pool. The largest one measured 140 millimeters.

BALISTAPUS ACULEATUS (Linnæus).

BALISTAPUS UNDULATUS (Park).

$$
\text { Family MONACANTHID E. }
$$

OSBECKIA SCRIPTA (Osbeck).

ALUTERA MONOCEROS (Osbeck).

\section{Family TETRAODONTID A. ${ }^{1}$}

SPHEROIDES OCELLATUS (Osbeck).

Two small specimens from the pools are referred with some doubt to this species.

TETRAODON HISPIDUS Linnæus.

\section{Family DIODONTIDE.}

DIODON HOLOCANTHUS Linnæus.

Family SCORPAENID AE.

SEBASTOPSIS GUAMENSIS (Quoy and Gaimard).

Thirteen specimens of this species were taken in the tide pools.

SCORPANOPSIS GIBBOSA (Bloch and Schneider).

SYNANCEJA VERRUCOSA Bloch and Schneider.

(Emmedrichthys vulcanus Jordan and Rutter.)

One example of this species was secured in the market. An examination of the type of Emmedrichthys vulcanus Jordan and Rutter ${ }^{2}$ shows that it probably belongs to this species, certainly to this genus. The type has a malformed dorsal, the posterior part having been injured, but otherwise it agrees with specimens of this species except in color, it being plain black. The Okinawa specimen, several from Samoa, and those generally described, have a white band on the caudal. The Okinawa example has, besides that of the caudal, a white band crossing the body along a vertical through the soft dorsal and anal. The whole body is mottled with shades and tints of brown.

Family PLATYCEPHALIDE.

PLATYCEPHALUS INDICUS (Linnæus).

THYSANOPHRYS CROCODILUS (Tilesius).

1 Spheroides alboplumbeus (Richardson).

Tetraodon meleagris (Lacépède).

Family CHEILODACTYLIDE.

Goniistius zonatus (Cuvier and Valenciennes).

2 Proc. Cal. Acad. Sci., ser. 2, vol. 6, 1896, pp. 221 and $562 \frac{1}{2}$. 


\section{Family LATILIDÆ.}

LATILUS JAPONICUS (Houttuyn).

\section{Family OSPHROMENID压.}

POLYACANTHUS OPERCULARIS (Linnæus).

Three specimens from the Imperial University, bearing the native name Tu-iwo, are said to have come from Okinawa.

\section{Family GOBIID $\mathbb{E}^{1}{ }^{1}$}

DORYPTENA OKINAW SE Snder.

\section{Plate 67, fig. 2.}

Doryptena okinawæ SNyder, Proc. U. S. Nat. Mus., vol. 35, 1909, p. 103.

Pools at Naha.

EVIOTA ABAX (Jordan and Snyder).

A few examples of this species do not appear to differ in any way from others taken at Tanegashima and Misaki. The first two dorsal rays are sometimes lengthened to form a filament.

EVIOTA ZONURA Jordan and Seale.

Numerous specimens of this form agree in every particular except color with examples from Samoa. The color is a little more intense in the Okinawa specimens, the pigment dots on the head tending to cluster in blotches, the scales usually being stippled near their edges, and the paired fins somewhat dusky. The lateral series of scales number 22 or 23 in individuals from both Samoa and Okinawa-not 28 . Occasionally specimens have the first and second dorsal rays greatly elongate and closely united by membrane, thus forming a flat filament. The teeth of the upper jaw are in two series, an outer row of large canines and an inner band of small teeth. On the lower jaw are an outer and an inner row of canines, between which is a band of smaller teeth. It is usual to find one or two enlarged canines on each side of both jaws. The teeth of E. ephiphanes, the type of the genus, are similar.

\section{HETERELEOTRIS ARENARIUS Snyder.}

Plate 67, fig. 3.

Hetereleotris arenarius SNYDER, Proc. U. S. Nat. Mus., vol. 36, 1909, p. 100.

Sandy pools near Naha; apparently rare.

GNATHOLEPIS SINDONIS Snyder.

Plate 68, fig. 1.

Gnatholepis sindonis SNyder, Proc. U. S. Nat. Mus., vol. 35, 1909, p. 101.

One specimen found in the market. 
CTENOGOBIUS ABEI Jordan and Snyder.

Five specimens, males and females, 30 to 40 millimeters long, are identified with $C$. abei. They are like the typical examples in all details of structure except that the dorsal spines are not filamentous. They differ somewhat in color, the bands of the body being less regular, the stripes of the caudal peduncle interrupted and inconspicuous, and the black spot on the spinous dorsal somewhat less distinct.

The species seems to be closely related to Ctenogobius (Vaimosa) fontinalis, ${ }^{1}$ which has the opercles partly scaled, the genus Vaimosa being synonymous with Mugilogobius Smitt, of which C. abei is said to be the type. ${ }^{2}$ It may be remarked that of 20 cotypes of $C$. fontinalis none has the spinous dorsal bordered with black as figured, but all have it light, and in many cases the black blotch near the middle is reduced to a small spot much like that seen in $C$. abei. Some specimens also have a light stripe near edge of soft dorsal.

The writer retains the genus Ctenogobius as used by Jordan and Snyder in The Gobioid Fishes of Japan. The tongue furnishes no reliable character for dividing the group, as in some cases ( $C$. virgatulus, $C$. pflaumi, and others) it may be concave, truncate, or even convex in different individuals of the same species. The condition of the opercle is apparently of no aid, for when a few scales are present they represent merely a more or less pronounced downward projection of the scaled area of the nape, which is itself often more or less naked $(C$. similis, C.gymnauchen).

CTENOGOBIUS BERNADOUI (Jordan and Starks).

This species was based on a specimen of doubtful origin, " "probably Korea," and it is therefore of great interest that a second example, in all appearances like the type, was found in the market at Naha.

Coryphopterus can not include this species, C. glaucofrænum, the type of the genus, having the head scaleless. ${ }^{4}$ C. bernadoui has a small patch of minute scales on upper part of opercle.

CTENOGOBIUS CANINUS (Cuvier and Valenciennes).

One specimen from the Naha market. There are a few large scales on the upper edge of the opercle, not more than 2 rows; the caudal is rather acutely rounded, the membrane with small, elongate black spots; ventrals jet black.

\section{CTENOGOBIUS CAMPBELLI Jordan and Snyder.}

This species has been known only from the type collected by Jordan and Snyder at Wakanoura, Japan. Six examples were secured at Naha. They do not differ from the type except in having the spots more sharply defined. The tongue is slightly notched in some specimens, truncate in others.

- Gill, Proc. Acad. Nat. Sci. Phila., 1863, p. 262; also Jordan and Everman, Fishes North and Middle America, p. 2219. 
CTENOGOBIUS GYMNAUCHEN (Bleeker).

One specimen about 40 millimeters long was secured near Naha. It is very light in color, but differs in no other way from Japanese examples.

\section{MAPO CRASSICEPS Jordan and Seale.}

This species is rather common in the pools near Naha. It is easily distinguished from similar looking gobies by the short, rounded ventral disk, the anterior part of which is markedly fleshy. The Okinawa specimens differ in no way from Samoan examples. All have scales on the upper part of the opercle.

MAPO FUSCUS (Rüppell).

Only 5 small examples were secured from the pools. Tongue immarginate; occiput scaled, sometimes to the eyes, although a narrow, naked space may usually be found just behind the eyes; snout rather pointed; chin with somewhat distinct, brown spots; sides with large brown clouds and many narrow indefinite stripes, the latter easily distinguishing the species from $G$. pæcitichthys, which it resembles in general appearance.

\section{MAPO AEOLOSOMUS (Ogilby).}

Numerous individuals of this species collected in the pools at Naha differ in no way from specimens collected at Lord Howe Island by Mr. E. R. Waite. The species is also found in Samoa, having been recorded as G.fuscus, "young with dark crossbands."

The teeth are in narrow bands on the jaws; none on the vomer and palatines. The outer teeth of the upper jaw are enlarged and curved, the inner ones small except one or two on each side which are considerably enlarged. The outer row on the lower jaw are much enlarged, one or two on each side being canine-like and especially strong. The tongue is emarginate.

\section{AMBLYGOBIUS NARAHARE Snyder.}

Plate 68, fig. 2.

Amblygobius naraharæ Snyder, Proc. U. S. Nat. Mus., vol. 35, 1909, p. 101.

Tide pools at Naha.

\section{PERIOPHTHALMUS CANTONENSIS (Osbeck).}

Abundant on the flat tidelands where thousands may be seen in long skirmish lines advancing ahead of the incoming tide or following the receding water.

\section{ZONOGOBIUS SEMIDOLIATUS (Cuvier and Valenciennes).}

Numerous specimens 38 millimeters long were found in the rock pools. The species also occurs at Tanegashima.

\section{XENISTHMUS PRORIGER Snyder.}

Plate 68, fig. 3.

Xenisthmus proriger SNYder, Proc. U. S. Nat. Mus., vol. 35, 1909, p. 105.

Pools at Naha. 


\section{FAMILY PTEROPSARIDA.}

PARAPERCIS HEXOPHTHALMA (Ehrenberg).

Six specimens of this species were secured in the market at Naha. A description of one measuring 180 millimeters follows.

Head 3.5 in the length; depth 6.2 ; depth caudal peduncle 3 in head; eye 4.5 ; snout 2.5 ; interorbital space 8.6 ; D. V., 21 ; A. 17 ; scales lateral series 64 ; between lateral line and origin of dorsal 18 .

The snout is pointed, the mouth large, maxillary reaching a vertical through anterior edge of pupil. Teeth simple, occurring in narrow bands on jaws and vomer, the palatines being naked; outer side of upper jaw with a row of enlarged, simple teeth that curve backward; front of lower jaw with similar teeth which are followed by a short space in which small teeth only are present; these in turn followed by 3 large curved canines and then a single row of smaller teeth. There are 13 very short gill-rakers, 9 of which are on the lower limb of the arch. Of the dorsal spines, the third and fourth are highest. The highest rays of the dorsal are located near the middle of the fin; their length contained 2 times in the head. The anal is inserted directly beneath the fourth dorsal ray. The posterior rays of dorsal and anal do not reach the base of caudal. The caudal is somewhat rounded or truncate posteriorly except for one or two of the upper rays which project in a sharp point. Pectoral rounded, reaching a vertical through anal opening. Ventral rays broadened and much thickened near tips; the next to inner ray longest.

The number of dorsal spines does not vary from 5 in the 6 specimens. There are from 19 to 21 dorsal rays and 17 or 18 anal rays.

Color in life, brownish gray above, grayish white beneath; upper two-thirds of body with many small spots with brown centers and lighter margins; head greenish gray, bluish white beneath; snout with ocelli, the centers of which are light brown, the margins orange; sides of head with orange spots; sides of body above middle of anal with three conspicuous ocelli with brownish black centers and lemon yellow rings. Dorsal lemon yellow, narrowly edged with white; with three rows of dark brown spots surrounded with transparent rings. Anal similar to dorsal except that the spots are surrounded by a pearly white area. Caudal with a large median, brownish black area, above and back of which are many smaller spots; black area with a posterior margin of dead white.

In spirits the brownish black figures only persist.

Young examples have 6 or 7 ocelli in line with the 3 large ones above anal fin, the anterior ones disappearing with age.

PARAPERCIS TETRACANTHA (Lacépède).

There are no teeth on the palatines. The posterior middle of caudal has a large, square, dead white spot. 


\title{
Family PLEURONECTIDA.
}

PLATOPHRYS MYRIASTER (Temminck and Schlegel).

One small specimen from a pool.

\section{Family SOLEIDÆ.}

ZEBRIAS JAPONICUS (Bleeker).

One specimen measuring 42 millimeters, from a pool.

PARDACHIRUS PAVONINUS (Lacépède).

Two small specimens from a pool. Neither has scales on the fin rays, but otherwise both agree perfectly with descriptions of the species.

TRULLA ITINA Snyder.

Plate 69, fig. 1.

Trulla itina Snyder, Proc. U. S. Nat. Mus., vol. 36, 1909, p. 609.

\section{Family CALLIONYMIDE.}

SYNCHIROPUS OCELLATUS (Pallas).

One specimen from the pools.

\section{Family GOBIESOCID $\mathbb{E}$.}

ASPASMA MINIMA (Doderlein).

\author{
Plate 69, fig. 2.
}

A single specimen of a species that is identified with some doubt as Aspasma minima was taken in a pool near Naha. Many specimens of the same form were taken near Misaki, Japan. They agree closely with Doderlein's description, except in the number of rays in the anal fin, which are there given as 5. Among 14 examples it was found that 2 had 6,8 had 7 , while 4 had 8 rays. The dorsal has 7 rays. The nostrils are tubular. The teeth are blunt, in 2 series on the upper jaw, the inner row having 4 teeth on each side. The teeth of the lower jaw are in a single series, flattened laterally, the edges concave. Pseudobranchiæ are present; gills developed on 3 arches. The ventrals are united laterally with the pectorals. A small anal papilla is present.

In life the color is brownish olive, changing on immersion in spirits to bright reddish, then slowly fading through flesh color to pale yellowish white.

The species inhabits the outlying tide pools. Nothing could be learned of its habits, and individuals were seen only after the water had been thoroughly poisoned with formalin, chloride of lime, or other irritating matter.

\section{ASPASMA MISAKIA Tanaka.}

Plate 69, fig. 3.

Twelve specimens of this species were taken in the pools at Naha, where it appears to be more commonly represented than at Misaki. Examples were taken at Tanegashima. At Misaki it appeared to be associated with the above species. A figure drawn before the species was described by Mr. Tanaka is here reproduced. 


\section{Family BLENNIIDÆ.}

ENNEAPTERYGIUS ETHEOSTOMA (Jordan and Snyder).

The dorsal contour of the snout is straight or concave, more often concave, but not convex as originally figured.

In life the body is grayish white with a yellowish tint, the yellow more pronounced on the ventral parts of the sides; upper parts reddish brown, the lighter body color showing in a larger or smaller degree near the center of each scale; bands of body brownish, the scales which border the bands edged with reddish; snout, chin, sides of head and throat suffused with brick red; fins with narrow bands of brick red, the color being located only on the rays and spines; lower rays of pectoral suffused with yellow.

The species appears to be rare at Naha, 3 specimens only having been secured.

ENNEAPTERYGIUS TUSITALE Jordan and Seale.

Enneapterygius pardochir Jordan and Seale, Bull. U. S. Bur. Fish., vol. 25, 1905, p. 417 (females).

A dissection of 10 specimens each of the dusky $E$. tusitatæ and the lighter colored E. pardochir leads to the conclusion that both are representatives of the same species, $E$. pardochir being described from a female. The figure of $E$. tusitalæ shows the spinous and rayed dorsals united at their bases, a condition not to be found in the cotypes.

\section{ALTICUS ELLIPES (Jordan and Starks).}

A small nasal tentacle is present.

In life the sides of the head and body have many dark-edged pearly ocelli, those of the body being elongate while those of the head are nearly round, the latter varying in number and intensity of color.

ALTICUS NOVEMMACULOSUS Snyder.

Plate 69, fig. 4.

Alticus novemmaculosus SNYDER, Proc. U. S. Nat. Mus., vol. 35, p. 107.

Abundant in the pools at Naha.

SALARIAS FASCIATUS (Bloch).

This species was recorded by Jordan and Snyder ${ }^{1}$ as $S$. ceramensis Bleeker.

\section{SALARIAS LINEATUS Bleeker.}

SALARIAS ANDERSONI Jordan and Starks.

In life the spots on the sides are brownish gray above, becoming pale, pearly blue on lower parts; spots on side of head with a greenish tint; large spot anterior to base of dorsal light golden brown, bordered by pearly gray, outside of which is a broader border of olive brown; body brownish olive; membranes of dorsal and caudal transparent olive, narrowly edged with pale reddish; spines and rays alternately 
banded with brownish olive and greenish gray; anal rays tipped with yellowish olive.

SALARIAS MUSCARUS Snyder.

Plate 70, fig. 1.

Salarias muscarus Snyder, Proc. U. S. Nat. Mus., vol. 35, 1909, p. 109.

One specimen from a pool at Naha.

SALARIAS SINUOSUS Snyder.

Plate 70, fig. 2.

Salarias sinuosus SNyder, Proc. U. S. Nat. Mus., vol. 35, 1909, p. 109.

Pools at Naha.

SALARIAS QUADRICORNIS Cuvier and Valenciennes.

Scartichthys enosimæ Jordan and SNyder, Proc. U. S. Nat. Mus., vol. 25, 1903, p. 460.

Salarias rivulatus Jordan and Seale, Bull. U. S. Bur. Fish., vol. 25, p. 429.

Salarias enosimæ appears to differ in no way from $S$. quadricornis. $S$. quadricornis differs from $S$. rivulatus in having tentacles on the nape. The latter is apparently related to S. zebra of Hawaii. Specimens recorded as $S$. rivulatus from Samoa prove on close examination to be representatives of $S$. quadricornis.

PETROSCIRTES LOXOZONUS Jordan and Starks.

The canines of the upper jaw are separated from the other teeth by a conspicuous open space. Curved canines, much longer than those above, are present in the lower jaw, no space existing between them and the other teeth. On each side of lower jaw, at angle of mouth is a peculiar flap, above which the lip forms a small fold partly inclosing the upper canine.

Color in life: Body with narrow, pearly white bands and reticulations which along the back inclose deep green areas that are margined with olive; on sides, the green areas extend downward and become brownish; other parts light olive, growing yellowish toward the caudal and whitish on the abdomen; chin yellowish, with small olive spots; spinous dorsal yellowish olive, with light yellow stripes; soft dorsal yellow, with oblique pearly white stripes; caudal yellow edged with red, the filamentous tips bright red; anal yellow, with oblique lines and a narrow margin of pearly white; ventrals bright yellow.

\section{ENCHELYURUS HEPBURNI Snyder.}

Plate 70, fig. 3.

Enchelyurus hepburni Snyder, Proc. U. S. Nat. Mus., vol. 35, 1909, p. 110.

Pools at Naha.

CRISTICEPS FLAMMEUS Jordan and Starks.

This species is abundantly represented at Okinawa, while it is comparatively rare at Tanegashima where it was first discovered. Large, flat tentacles are present at the nostrils. 


\section{$2 \mathrm{BHL}$ Biodiversity Heritage Library}

Snyder, John Otterbein. 1912. "The fishes of Okinawa, one of the Riu Kiu Islands." Proceedings of the United States National Museum 42(1913), 487-519. https://doi.org/10.5479/si.00963801.42-1913.487.

View This Item Online: $\underline{\text { https://www.biodiversitylibrary.org/item/32500 }}$

DOI: https://doi.org/10.5479/si.00963801.42-1913.487

Permalink: https://www.biodiversitylibrary.org/partpdf/13678

\section{Holding Institution}

Smithsonian Libraries

\section{Sponsored by}

Smithsonian

\section{Copyright \& Reuse}

Copyright Status: NOT_IN_COPYRIGHT

This document was created from content at the Biodiversity Heritage Library, the world's largest open access digital library for biodiversity literature and archives. Visit BHL at https://www.biodiversitylibrary.org. 